\title{
A Review: Chemical Treatments of Rice Husk for Polymer Composites
}

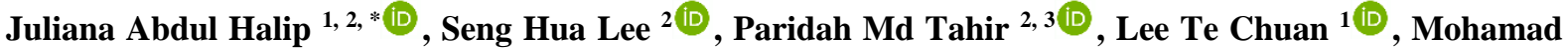 \\ Ali Selimin 1(D), Harmaen Ahmad Saffian 2 (D) \\ 1 Faculty of Technology Management and Business, Universiti Tun Hussein Onn Malaysia, Parit Raja, Batu Pahat, Johor, \\ 86400, Malaysia; julianaah@uthm.edu.my (J.A.H.); aliselimin@uthm.edu.my (M.A.S.); tclee@uthm.edu.my (L.T.C.); \\ 2 Institute of Tropical Forestry and Forest Products, Universiti Putra Malaysia, Serdang, Selangor, 43400, Malaysia; \\ lee_seng@upm.edu.my (L.S.H.); parida@upm.edu.my (P.M.T.); \\ 3 Faculty of Forestry, Universiti Putra Malaysia, Serdang, Selangor, 43400, Malaysia; parida.introp@ gmail.com (P.M.T.); \\ * Correspondence: julianaah@uthm.edu.my;
}

Scopus Author ID 57193947939

Received: 7.12.2020; Revised: 3.01.2021; Accepted: 4.01.2021; Published: 6.01.2021

\begin{abstract}
Rice husk is one of the agricultural by-products produces worldwide. During the recent decade, much attention has been focused on rice husk utilization for composite materials. Apart from the rice industry's huge amount of rice husk, it has a dominant agricultural waste position due to its great properties. The treatments or modifications of fiber surface properties typically increase the adhesion properties of fibers and polymers yet affect the polymer composite's physical and mechanical properties. Prior studies revealed that chemical treatments consider as one of the most used methods for the surface treatments of agricultural fibers. This paper provides an overview of the rice husk as a reinforcing material in polymer composite. Various types of chemical treatments such as alkali, benzylation, anhydride, silane, and acetylation applied on rice husk polymer composite and their effect on physical and mechanical properties were investigated based on previous literature. Rice husk polymer composites with different chemical treatments and polymers were compiled, and their basic properties were reported. Therefore, this paper will benefit future works on rice husk chemical treatments in a composite application.
\end{abstract}

Keywords: rice husk; rice industry; agricultural.

(c) 2020 by the authors. This article is an open-access article distributed under the terms and conditions of the Creative Commons Attribution (CC BY) license (https://creativecommons.org/licenses/by/4.0/).

\section{Introduction}

In recent years, there is remarkable progress in the utilization of natural fibers, mostly due to the concern and high dependency on petroleum-based synthetic polymers. Zhang et al. [1] stated that the most commonly used synthetic polymers, namely polypropylene, polyethylene, and polyvinyl chloride, are synthesized from crude petroleum oil, which generated huge stress on the energy for a long haul. The polymer can be either natural or synthetic. There are two major classes of synthetic polymer; thermosetting and thermoplastic polymers. Thermosetting polymers are defined as those polymers which become irreversibly hard once cured, while thermoplastic polymers are those polymers that can be reversible and reformed. In a prior study done by Puglia et al. [2], the production of natural fiber-based thermoplastic composites represents a promising possibility of producing a biodegradable material with additional benefits for the environmental impact and aimed for packaging and automotive applications. Natural fibers have been used as reinforcement materials in polymer 
composite for the last two decades, especially using low melting point thermoplastics polymers [3]. Natural fibers gain much attention from researchers as they are abundant, biodegradable, inexpensive, and lightweight [4-9]. Some examples of natural fibers include jute, hemp, kenaf, flax, abaca, sisal, bagasse, corn silk, rice husk, pineapple, oil palm, acai, peanut husk, rice husk [4,5,10-12]. Natural fibers can be categorized into plant and animal fibers based on their origin. Plant fibers gained more attention from the research. As reported by previous studies, plant fibers are classified into six types; wood (collected from wood, e.g., softwood and hardwood), bast fiber (collected from the skin or bast surrounding the stem, e.g., jute, kenaf, hemp, ramie, rattan, soybean, vine, and banana fibers), leaf (collected from leaves, e.g., agave and sisal), seed (collected from seeds or seed cases, e.g., kapok, cotton, rice husk), fruit (collected from the fruit of the plant, e.g., coir and coconut) and grass/stalk (collected from stalks of the plant, e.g., straws of wheat, rice, barley and other crops including bamboo and grass) $[13,14]$.

Paddy (Oryza sativa) is one of the most widespread crops globally, and it produces a high amount of agricultural waste, namely rice husks and stalks. Rice husk is classified as an agricultural waste found abundantly in rice-producing countries, including China, India, Indonesia, Bangladesh, and Malaysia [15]. In a review article by Paridah et al. [14], rice husk is one of the agricultural residues obtained daily from rice processing mills. Rice husks are used in various applications, including composites, insulation material, fertilizer, and fuel [16]. Most of the natural fibers are motivated by potential advantages of high mechanical properties, low-cost material, lightweight, high in supply, renewable, environmentally friendly, recyclability, and degradability features [17-19]. Therefore, natural fibers are used as a filler and reinforcement in thermoplastic polymers. There is abundant literature reporting the applications, manufacturing, physical and mechanical properties of natural fibers.

However, the manufacturing of natural fiber polymer composites has some limitations due to natural fibers' inherent properties that vary significantly from those of synthetic fibers [20]. One of the major limitations of using natural fiber is the interface of natural fiber and polymer. Commonly, the moisture absorption in composite with natural fibers' presence is high due to the presence of hydroxyl and other polar groups in various constituents of natural fibers, which leads to weak interfacial bonding between fibers and matrix polymer [21]. Therefore, surface modifications such as chemical treatment are necessary to improve the performance of the biocomposites. The present article deals with an overview of rice husk as a reinforcing material in a polymer composite, various chemical treatments on rice husk, and properties of rice husk polymer composites to provide comprehensive information on the chemical treatment of rice husk as polymer composite.

\section{Properties of Rice Husk}

Rice husk is the hard-protective part covering a rice grain. Fijalkowski et al. [22] stated that rice husks barrier layers and formations of silica are created on the surfaces of husks and stem as a result of biochemical reactions photosynthesis. At the same time, these barrier layers protect a plant and its part against external environmental stresses. As reported by a previous study, a ton of rice produced approximately 0.23 tons of rice husks [23]. Apart from the high amount produced worldwide, rice husk has a dominant agricultural waste position due to its great properties. FAO [24] stated that about 122-163 million metric tons of rice husks are being disposed of as waste annually worldwide in 2012. 
Currently, rice husk is underutilized, and most of them are burnt or disposed of in the landfill $[25,26]$. Few studies were carried out on the evaluation of chemical compositions of rice husk [17,27]. In their study, rice husk consists of $25-48 \mathrm{wt} \%$ cellulose, $18-25 \mathrm{wt} \%$ hemicelluloses, 12-31 wt\% lignin, 15-17 wt\% silica 14-17\% wt\% wax (Table 1). Due to similar cellulose content but lower lignin and hemicellulose content of rice husk compared to wood, rice husk flour can be processed at a higher temperature than wood [28].

In a previous report, bast fiber, namely hemp, jute, flax, and kenaf bast, have densities of $1.48 \mathrm{~g} / \mathrm{cm}^{3}, 1.46 \mathrm{~g} / \mathrm{cm}^{3}, 1.50 \mathrm{~g} / \mathrm{cm}^{3}$, and $1.40 \mathrm{~g} / \mathrm{cm}^{3}$, respectively [29]. This indicates that rice husk has a slightly lower density compared to bast fibers. Additionally, there is a wide application range of rice husk due to its high availability, toughness, resistance to weathering, and abrasion [30]. Interestingly, the high silica content in rice husk provides high stiffness and holds the composite's potential flame retardancy properties [31]. In another report, Kumar et al. [32] also reported that rice husk has high insulating property (better thermal insulation), making it suitable for making bricks. Additionally, rice husk is also used as industrial raw materials, including insulating board [34]. As reported by a previous study, rice husks are high in ash compared to other biomass fuels range 10-20\% [33]. The composition of rice husk depends on many factors, namely rice variety, type of fertilizer used, soil chemistry, and even the geographic localization of the production [34].

Table 1. Chemical constituent and physical properties of rice husk $[27,35]$.

\begin{tabular}{l|l} 
Property \\
\hline Constituent $(\%)$ & $25-48$ \\
\hline Cellulose & $18-25$ \\
\hline Hemicellulose & $12-31$ \\
\hline Lignin & $15-17$ \\
\hline Silica $\left(\mathrm{SiO}_{2}\right)$ & $14-15$ \\
\hline Wax & $2-5$ \\
\hline Solubles & \multicolumn{2}{|l}{} \\
\hline Physical properties & 6.60 \\
\hline Particle size $(\mu \mathrm{m})$ & 1.40 \\
\hline Surface area $\left(\mathrm{m}^{2} / \mathrm{g}\right)$ & 2.20
\end{tabular}

\section{Rice Husk in Polymer Composite}

Investigation on rice husk as a polymer composite has been carried out in many studies [36-46]. In a previous study by Shivappa et al. [42], polymer composites were prepared with unmodified rice husk flour as a filler and unsaturated vinyl ester resin matrix at fiber loading of $0 \%, 2.5 \%, 7.5 \%$, and $10 \%$ by weight. In their study, as the fiber loading increased, the flexural strength was increased; however, decreased the tensile strength at $20 \%$ fiber loading. In another study, Ayrilmis et al. [44] stated that the flexural and tensile properties of lignocellulosic filled-PP composite panels were greatly improved by the incorporation of aramid fabric. The composite panels having aramid fabric positioned in two layers close to surface layers had the highest bending and tensile properties. Although there is a wide variety of polymer that can be used as the matrix for producing rice husk-filled polymer composites, polylactic acid (PLA), polyethylene (PE), polypropylene (PP), and polyvinyl chloride (PVC) are among the most popular selections. Every polymer resulted in a composite with different properties, as can be seen by the review of Arjmandi et al. [27].

\section{Chemical Treatment of Rice Husk}


There are many chemical treatments in natural fibers; alkaline treatment (mercerization), benzylation, acetylation, anhydride treatment, silane treatment, treatment with stearic acid, peroxide treatment, permanganate treatment, isocyanate treatment, and plasma treatment [47,48]. Among these chemical treatments, alkaline treatment, known as mercerization, is one of the most used treatments for natural fibers, commonly using $\mathrm{NaOH}$ [49-52]. Li et al. [48] explained that alkaline treatment's major modification is the disruption of hydrogen bonding in the network structure, thereby increasing surface roughness, thus providing better fiber quality. Additionally, this treatment increases cellulose content, removes a certain amount of lignin, wax, and oils covering the external surface of the fiber cell wall, depolymerizes cellulose, and exposes the short-length crystallites [21,52-54]. Chemical treatment also improves the wetting ability of the fiber [47].

As tabulated in Table 2, alkaline treatment is the most common treatment used for rice husk. Some of the alkaline treatment is also incorporate with anhydride treatment. Most the previous studies found that alkaline treated rice husk improved the mechanical properties of rice husk reinforced polymer composite [55-60]. Ndazi et al. [55] discussed rice husk's chemical and thermal stability against alkaline treatment with 2 to $8 \% \mathrm{w} / \mathrm{v} \mathrm{NaOH}$. Findings revealed that the proportion of lignin and hemicellulose in rice husk treated with $\mathrm{NaOH}$ decreased significantly. In a previous study done by Emdadi et al. [58], rice husk was treated using alkaline at $1 \% \mathrm{KOH}$ to evaluate treated fibers' water absorption properties. The finding shows that alkaline treated fiber improves the bond strength of $\mathrm{O}-\mathrm{Si}-\mathrm{O}$ of the silica and reduces the quantity of amorphous silica. In another study by Ghani et al. [57], alkali-treated rice husk with additional maleic anhydride grafted polyethylene (MAPE) shows a rougher surface compared to untreated rice husk and this surface enhance the compatibility between fibers and matrix. As mentioned by Syafri et al. [61], a rougher surface could improve the compatibility between fibers and matrix.

Table 2. Studies on chemical treatment of rice husk polymer composite.

\begin{tabular}{|c|c|c|c|c|c|c|c|}
\hline Authors & Polymer & $\begin{array}{l}\text { Size } \\
(\mu \mathrm{m})\end{array}$ & Treatment & $\begin{array}{c}\text { Flexural } \\
\text { (MPa) }\end{array}$ & $\begin{array}{l}\text { Young Modulus } \\
\text { (MPa) }\end{array}$ & $\begin{array}{c}\text { Tensile Strength } \\
\text { (MPa) }\end{array}$ & $\begin{array}{c}\text { Tensile Modulus } \\
\text { (MPa) }\end{array}$ \\
\hline $\begin{array}{l}\text { Wang et al. } \\
{[60]}\end{array}$ & $\mathrm{PVC}$ & 100 & $\begin{array}{c}\text { Alkaline }(\mathrm{NaOH} 4 \%) \\
\& \text { Anhydride }\end{array}$ & $\sim 44$ & $\mathrm{n} / \mathrm{a}$ & $\mathrm{n} / \mathrm{a}$ & $\mathrm{n} / \mathrm{a}$ \\
\hline $\begin{array}{l}\text { Wang et al. } \\
{[60]}\end{array}$ & PVC & 100 & $\begin{array}{l}\text { Benzoylation } \\
\text { \& Anhydride }\end{array}$ & $\sim 46$ & $\mathrm{n} / \mathrm{a}$ & $\mathrm{n} / \mathrm{a}$ & $\mathrm{n} / \mathrm{a}$ \\
\hline $\begin{array}{l}\text { Ghani et al. } \\
\text { [57] }\end{array}$ & rHDPE & $\mathrm{n} / \mathrm{a}$ & $\begin{array}{c}\text { Alkaline }(\mathrm{NaOH} 0.5 \\
\text { N) \& Anhydride } \\
\text { (MAPE) }\end{array}$ & $\sim 24-34$ & $\sim 570-1500$ & $\mathrm{n} / \mathrm{a}$ & $\sim 180-750$ \\
\hline $\begin{array}{l}\text { Emdadi et al. } \\
{[58]}\end{array}$ & PVA & $45-70$ & Alkaline (KOH 1\%) & $\mathrm{n} / \mathrm{a}$ & $\mathrm{n} / \mathrm{a}$ & $\mathrm{n} / \mathrm{a}$ & $\mathrm{n} / \mathrm{a}$ \\
\hline $\begin{array}{l}\text { Luna et al. } \\
{[59]}\end{array}$ & $\mathrm{PP}$ & $\mathrm{n} / \mathrm{a}$ & Alkaline (NaOH 1\%) & $35-43$ & $\mathrm{n} / \mathrm{a}$ & $16-23$ & $\mathrm{n} / \mathrm{a}$ \\
\hline $\begin{array}{l}\text { Ayrilmis et } \\
\text { al. [44] }\end{array}$ & $\mathrm{PP}$ & 60 & $\begin{array}{c}\text { Anhydride (MAPP } \\
3 \%)\end{array}$ & 16.2 & 1845 & 9.6 & 2303 \\
\hline $\begin{array}{l}\text { Rahman et } \\
\text { al. [56] }\end{array}$ & $\mathrm{PE}$ & 209 & Alkaline (NaOH 5\%) & $\sim 32-37$ & $\sim 1100-2500$ & 14-19 & $\sim 1800-2300$ \\
\hline $\begin{array}{l}\begin{array}{l}\text { Rosa et al. } \\
{[38]}\end{array} \\
{[38}\end{array}$ & $\mathrm{PP}$ & $\mathrm{n} / \mathrm{a}$ & $\begin{array}{c}\text { Anhydride (MAPP } \\
0.5 \text { to } 2 \% \text { ) }\end{array}$ & $\mathrm{n} / \mathrm{a}$ & $\mathrm{n} / \mathrm{a}$ & $\mathrm{n} / \mathrm{a}$ & $\mathrm{n} / \mathrm{a}$ \\
\hline $\begin{array}{l}\text { Maziad et al. } \\
{[62]}\end{array}$ & $\begin{array}{l}\text { Rubber \& } \\
\text { LDPE }\end{array}$ & $\mathrm{n} / \mathrm{a}$ & $\begin{array}{l}\text { Silane (3-APE 1\%) } \\
\text { \& Anhydride } \\
\text { (MAH } 4 \text { phr) }\end{array}$ & $\mathrm{n} / \mathrm{a}$ & $\mathrm{n} / \mathrm{a}$ & $12-25$ & $140-400$ \\
\hline
\end{tabular}

$\mathrm{KOH}$ - Potassium hydroxide; MAPP- Maleic anhydride grafted polypropylene; PVA- polyvinyl alcohol; PPPoypropylene; LDPE- low-density polyethylene; 3-APE- 3-aminopropyl triethoxy silane; MAH- Maleic acid anhydride; PE- Polyethylene; PVC- Polyinyl chloride; rHDPE- recycled high density polyethylene; MAPEMaleic anhydride grafted polyethylene 
Apart from alkaline treatment, benzoyl chloride is also one of the most often used in fiber treatment. Benzylation treatment allows decreasing the hydrophilicity of the fibers. Benzoyl chloride includes benzoyl $\left(\mathrm{C}_{6} \mathrm{H}_{5} \mathrm{C}=\mathrm{O}\right)$, attributed to the decreased hydrophilic nature of the treated fiber and improved interaction with the hydrophobic matrix [43]. In a recent study, Wang et al. [60] studied two types of pretreatment on the rice husk; alkaline and benzoylation treatments. It was verified that benzoylation treatments were much better than alkaline treatments.

As stated by Li et al. [48], acetylation (also known as esterification method) treatment explains a reaction is introducing an acetyl functional group $\left(\mathrm{CH}_{3} \mathrm{COO}-\right)$ into an organic compound. Acetylation of natural fibers causes plasticization of cellulosic fibers. The reaction involves the generation of acetic acid $\left(\mathrm{CH}_{3} \mathrm{COOH}\right)$ as a by-product, which must be removed from the lignocellulosic material before the fiber is used. Acetylation treatment may perhaps stabilize the cell walls of plant fibers, especially in terms of humidity absorption.

Maleic anhydride-grafted polymers are also a common preference for rice husk polymer composites. As reported by a previous study, the major difference with other chemical treatments is that maleic anhydride is used to modify fiber surface and the matrix to achieve better interfacial bonding and mechanical properties in composites [48]. The PP chain allows maleic anhydride to be cohesive and produce maleic anhydride grafted polypropylene (MAPP). Next, the treatment of cellulose fibers with hot MAPP copolymers provides covalent bonds across the interface. A study done by Rosa et al. [38] treated the rice husk using MAPP, and the PP composites were prepared with up to $40 \mathrm{wt} \%$ rice husks. Finding revealed that the interfacial effect of the maleated PP was seen on the melt flow index of the composites. This study reported that the presence of the MAPP did not affect the composites' thermal properties but improved the storage modulus and loss modulus of the composites. Apart from MAPP, other types of maleic anhydride have also been used to manufacture rice husk polymer composites $[60,62]$.

Silane treatment normally reduces the number of cellulose hydroxyl groups in the interface of the fiber-matrix. In the presence of moisture, the hydrolyzable alkoxy group leads to the formation of silanols, whereas the silanol will react with the hydroxyl group and form stable covalent bonds to the cell wall that are chemisorbed onto the fiber surface [63]. Maziad et al. [62] investigated the effects of silane coupling agent on the properties of rice husk-filled melaic acid anhydride compatibilized with rubber and low-density polyethylene. In their study, silane treated rice husk has better tensile strength, hardness, Young's modulus, and impact strength than untreated samples. Additionally, Srisuwan et al. [64] reported that the flexural and tensile of silane-treated rice husk mixed with natural rubber as a polymer has small improvement compared to alkaline treatment.

\section{Conclusion}

Nowadays, natural plant fibers are gradually replacing synthetic fibers as reinforcement materials in various polymers. The advantages of rice husk fibers are low density, acceptable mechanical properties, and better thermal insulation properties. From literature, rice husk is successfully used as a filler or reinforcement in polymer composites. However, owing to its drawbacks mentioned in the previous section, chemical treatments are required to improve rice husk polymer composite's surface roughness and mechanical properties. The most used treatments are alkaline treatment, followed by a combination of alkaline and anhydride, benzylation, anhydrides, and silane treatments. These treatments improve the surface 
roughness and decreased hydrophilic properties of rice husk, thus enhancing the fiber quality before their application as a reinforcement material for composites.

\section{Funding}

This research was funded by Universiti Tun Hussein Onn Malaysia (UTHM), grant Tier 1 Vot H138.

\section{Acknowledgments}

The authors would like to acknowledge Universiti Tun Hussein Onn Malaysia (UTHM), for supporting this research.

\section{Conflicts of Interest}

The authors declare no conflict of interest.

\section{References}

1. Zhang, L.; Zhong, J.; Ren, X. Natural Fiber-Based Biocomposites. In: Green Biocomposites. Springer International Publishing, 2017; pp. 31-70.

2. Puglia, D.; Sarasini, F.; Santulli, C.; Kenny, J.M. Manufacturing of Natural Fiber / Agrowaste Based Polymer Composites. In: Green Biocomposites. Springer International Publishing, 2017; pp. 125-147, https://doi.org/10.1007/978-3-319-46610-1_6.

3. Nafdey, R.; Kaushik, G.; Telang, S.; Chel, A. Natural fiber reinforced polymer composite and their tensile properties - a review. Lett. Appl. Microbiol. 2020, 9, 1103-1110.

4. de Azevedo, A.R.G.; Marvila, M.T.; Tayeh, B.A.; Cecchin, D.; Pereira, A.C.; Monteiro, S.N. Technological performance of açaí natural fibre reinforced cement-based mortars. Journal of Building Engineering 2021, 33, 1-11, https://doi.org/10.1016/j.jobe.2020.101675.

5. Ilyas, R.A.; Sapuan, S.M.; Norizan, M.N.; Atikah, M.S.N.; Huzaifah, M.R.M.; Radzi, A.M.; Ishak, M.R.; Zainudin, E.S.; Izwan, S.; Azammi, A.N; Jumaidin, R. Potential of natural fibre composites for transport industry: a review. In: Prosiding Seminar Enau Kebangsaan. 2019, pp. 2-11.

6. Gholampour, A.; Ozbakkaloglu, T. A review of natural fiber composites: properties, modification and processing techniques, characterization, applications. Journal of Materials Science 2020, 55, 829-892, https://doi.org/10.1007/s10853-019-03990-y.

7. Todor, M.P.; Bulei, C.; Kiss, I.; Alexa, V. Recycling of textile wastes into textile composites based on natural fibres: the valorisation potential. IOP Conference Series: Materials Science and Engineering 2019, 477, 1-8, https://doi.org/10.1088/1757-899X/477/1/012004.

8. Attia, T. Natural Fiber Thermoplastic Composites with Biodegradant and Fire Retardant Additives. Int J Compos Mater. 2019, 9, 24-31.

9. Noryani, M.; Sapuan, S.M.; Mastura, M.T.; Zuhri, M.Y.M.; Zainudin, E.S. Material selection of natural fibre using a stepwise regression model with error analysis. Journal of Materials Research and Technology 2019, 8, 2865-2879, https://doi.org/10.1016/j.jmrt.2019.02.019.

10. Ali, G.W.; Abdel-Fattah, W.I.; Elhaes, H.; Ibrahim, M.A. Spectroscopic and modeling analyses of bimolecular structure of corn silk. Biointerface Res Appl Chem. 2019, 9, 4581-4585, https://doi.org/10.33263/BRIAC96.581585.

11. Ali, A.; Ing, A.W.C.; Abdullah, W.R.W.; Hamzah, S.; Azaman, F. Preparation of high-performance adsorbent from low-cost agricultural waste (Peanut husk) using full factorial design: Application to dye removal. Biointerface Res Appl Chem. 2020, 10, 6619-6628, https://doi.org/10.33263/BRIAC106.66196628.

12. Srinivasababu, N. Tensile Behaviour of Centrally Holed Pineapple Fibre Reinforced Vinyl Ester Composites. In: Pineapple Leaf Fibers. Springer, Singapore; 2020; pp. 235-247, https://doi.org/10.1007/978-981-15-1416-6_11.

13. Fahim, M.; Chand, N. Natural fibers and their composites. In: Tribology of natural fiber polymer composites. Elsevier, 2008; pp. 1-58, https://doi.org/10.1533/9781845695057.1.

14. Paridah, M.T.; Juliana, A.H.; Zaidon, A.; Khalil, H.P.S.A. Nonwood-Based Composites. Curr. For. Rep. 2015, 1, 221-238, https://doi.org/10.1007/s40725-015-0023-7.

15. Aprianti, E.; Shafigh, P.; Bahri, S.; Nodeh, J. Supplementary cementitious materials origin from agricultural wastes - A review. Constr. Build. Mater. 2015, 74, 176-187, https://doi.org/10.1016/j.conbuildmat.2014.10.010. 
16. Ramamoorthy, S.K.; Skrifvars, M.; Persson, A.; Persson, A. A Review of Natural Fibers Used in Biocomposites: Plant, Animal and Regenerated Cellulose Fibers. Polym. Rev. 2015, 55, 107-162, https://doi.org/10.1080/15583724.2014.971124.

17. Faruk, O.; Bledzki, A.K.; Fink, H.; Sain, M. Biocomposites reinforced with natural fibers : $2000-2010$. Prog. Polym. Sci. 2012, 37, 1552-1596, https://doi.org/10.1016/j.progpolymsci.2012.04.003.

18. Al-Oqla, F.M.; Alothman, O.Y.; Jawaid, M.; Sapuan, S.M. Processing and Properties of Date Palm Fibers and Its Composites. In: Biomass and Bioenergy: Processing and Properties. Springer International Publishing, 2014; pp. 1-25, https://doi.org/10.1007/978-3-319-07641-6_1.

19. Juliana, A.H.; Lee, S.H.; Paridah, T.; Ashaari, Z.; Lum, W.C. Development and Characterization of Wood and Non-wood Particle Based Green Composites Particle geometry. In: Green Biocompositess, Green Energy and Technology. Springer, 2017; pp. 181-198, https://doi.org/10.1007/978-3-319-46610-1_8.

20. Mohammed, L.; Ansari, M.N.M.; Pua, G.; Jawaid, M.; Islam, M.S. A Review on Natural Fiber Reinforced Polymer Composite and Its Applications. Int. J. Polym. Sci. 2015, 2015, https://doi.org/10.1155/2015/243947.

21. Mohanty, A.K.; Misra, M.; Drzal, L.T. Surface modifications of natural fibers and performance of the resulting biocomposites: An overview. Compos. Interfaces 2001, 8, 313-343, https://doi.org/10.1163/156855401753255422.

22. Mateusz, F.; Kinga, A.; Aleš, P.; Dora, K. Rice Husks-Structure, Composition and Possibility of Use them at Surface Treatment. Mater. Sci. Forum 2016, 844, 153-156, https://doi.org/10.4028/www.scientific.net/MSF.844.153.

23. Lim, S.; Yeong, T.; Yih, E.; Sim, S.; Nie, P.; Clarke, C. Biotransformation of rice husk into organic fertilizer through vermicomposting. Ecol. Eng. 2012, 41, 60-64, https://doi.org/10.1016/j.ecoleng.2012.01.011.

24. FAO Cereal Supply and Demand Brief Available online: http://www.fao.org/worldfoodsituation/csdb/en/ (accessed on Apr 15, 2018).

25. Sun, L.; Gong, K. Silicon-Based Materials from Rice Husks and Their Applications. Ind. Eng. Chem. Res. 2001, 40, 5861-5877, https://doi.org/10.1021/ie010284b.

26. Zhang, M.H.; Lastra, R.; Malhotra, V.M. Rice-husk ash paste and concrete: some aspects of hydration and the microstructure of the interfacial zone between the aggregate and paste. Cem. Concr. Res. 1996, 26, 963977, https://doi.org/10.1016/0008-8846(96)00061-0.

27. Arjmandi, R.; Hassan, A.; Majeed, K.; Zakaria, Z. Rice Husk Filled Polymer Composites. Int. J. Polym. Sci. 2015, 2015, 32, https://doi.org/10.1155/2015/501471.

28. Mart1'-Ferrer, F.; Vilaplana, F.; Ribes-greus, A.; Benedito-Borra, A.; Sanz-Box, C. Flour Rice Husk as Filler in Block Copolymer Polypropylene: Effect of Different Coupling Agents. J. Appl. Polym. Sci. 2006, 99, https://doi.org/10.1002/app.22717.

29. Sreenivas, H.T.; Krishnamurthy, N.; Arpitha, GR. A comprehensive review on light weight kenaf fiber for automobiles. Int. J Lightweight Mater. Manu. 2020, 3, 328-337, https://doi.org/10.1016/j.ijlmm.2020.05.003.

30. Arjmandi, R.; Hassan, A.; Zakaria, Z. 5 - Rice husk and kenaf fiber reinforced polypropylene biocomposites. In: Lignocellulosic Fibre and Biomass-Based Composite Materials. Jawaid, M.; Md Tahir, P.; Saba, N. Eds. Woodhead Publishing: 2017; pp. 77-94, https://doi.org/10.1016/B978-0-08-100959-8.00005-6.

31. Zhao, Q.; Zhang, B.; Quan, H.; Yam, R.C.M.; Yuen, R.K.K.; Li, R.K.Y. Flame retardancy of rice husk-filled high-density polyethylene ecocomposites. Compos. Sci. Technol. 2009, 69, 2675-2681, https://doi.org/10.1016/j.compscitech.2009.08.009.

32. Kumar, S.; Sangwan, P.; Dhankhar, R.M. V.; Bidra, S. Utilization of rice husk and their ash: A review. Res. J. Chem. Env. Sci 2013, 5, 126-129, https://doi.org/10.19026/rjaset.9.2606.

33. Sarangi, M.; Bhattacharyya, S.; Behera, R.C. Effect of temperature on morphology and phase transformations of nano- crystalline silica obtained from rice husk. Phase Transitions 2009, 82, 377-386, https://doi.org/10.1080/01411590902978502.

34. Setyo Muntohar, A. Utilization of Uncontrolled Burnt Rice Husk Ash In Soil Improvement. Dimens. Tek. Sipil 2002, 4, 100-105.

35. Nikmatin, S.; Hermawan, B.; Sukardan, D.; Irmansyah, I.; Suhartono, S.; Syafiuddin, A. Enhancement of physical, chemical, and mechanical properties of biocomposite for the fire resistant material application. Biointerface Res Appl Chem. 2020, 10, 5423-5428, https://doi.org/10.33263/BRIAC103.423428.

36. Choi, N.; Mori, I.; Ohama, Y. Development of rice husks - plastics composites for building materials. Waste Manag. 2006, 26, 189-194, https://doi.org/10.1016/j.wasman.2005.05.008.

37. Toro, P.; Quijada, R.; Murillo, O.; Yazdani-Pedram, M. Study of the morphology and mechanical properties of polypropylene composites with silica or rice-husk. Polym. Int. 2005, 54, 730-734, https://doi.org/10.1002/pi.1740.

38. Rosa, S.M.L.; Nachtigall, S.M.B.; Ferreira, C.A. Thermal and Dynamic-Mechanical Characterization of Rice-Husk Filled Polypropylene Composites. Macromol. Res. 2009, 17, 8-13, https://doi.org/10.1007/bf03218594. 
39. Nwanonenyi, S.; Ohanuzue, C.B.C. Effect of Rice-Husk Filler on Some Mechanical and End Use Properties of Low Density Polyethylene. J. Technol. Educ. Niger. 2011, 16, 102-108.

40. Nwanonenyi, S. Analysis of Mechanical Properties of Low Density Polyethylene / Rice-Husk Composite using Micro Mathematical Model Equations. IOSR J. Eng. 2012, 2, 399-407, https://doi.org/10.9790/30210203399407.

41. Atuanya, C.U.; Olaitan, S.A.; Akagu, C.C.; Onukwuli, O.D.; Menkiti, M.C. Effect of rice husk filler on mechanical properties of polyethylene matrix composite. Int. J. Curr. Res. Rev. 2013, 5, 111-118.

42. Shivappa; G.K.; Ananda, G.K.; Shivakumar N. Mechanical Characterisation of Rice Husk Flour Reinforced Vinylester Polymer Composite. Int. J. Innov. Res. Sci. 2013, 11, 6271-6278.

43. Cholachagudda, V. V.; Ramalingaiah, P.U. Mechanical characterisation of coir and rice husk reinforced hybrid polymer composite. Int. J. Innov. Res. Sci. 2013, 2, 3779-3786.

44. Ayrilmis, N.; Kwon, J.H.; Han, T.H. Improving Bending and Tensile Properties of Lignocellulosic Filled Polypropylene Composite Panels Using Aramid Fabric. Fibers Polym. 2014, 15, 2410-2415, https://doi.org/10.1007/s12221-014-2410-2.

45. Abdulkareem, S.A.; Amosa, M.K.; Adeniyi, A.G.; Adeoye, S.A.; Ajayi, A.K. Development of natural fibre reinforced polystyrene (NFRP) composites: Impact resistance study. In: IOP Conference Series: Materials Science and Engineering. 640(1); IOP Publishing, 2019; https://doi.org/10.1088/1757-899X/640/1/012059.

46. Jaya, H.; Noriman, N.Z.; Rahim, S.Z.A.; Omar, M.F.; Hamzah, R.; Dahham, O.S.; Umar, M.U. 2020, March. Mechanical properties of rice husk (Oryza sativa) reinforced low density polyethylene composites for industrial injection moulded parts. In: AIP Conference Proceedings. 2213(1), AIP Publishing LLC, 2020; https://doi.org/10.1063/5.0000402.

47. La Mantia, F.P.; Morreale, M. Green composites : A brief review. Compos. Part A 2011, 42, 579-588, https://doi.org/10.1016/j.compositesa.2011.01.017.

48. Li, X.; Tabil, L.G.; Panigrahi, S. Chemical Treatments of Natural Fiber for Use in Natural Fiber-Reinforced Composites : A Review. J. Polym. Environ. 2007, 15, 25-33, https://doi.org/10.1007/s10924-006-0042-3.

49. Oliveira Filho, E.G.D.; Luz, F.S.D.; Fujiyama, R.T.; Silva, A.C.R.D.; Candido, V.S.; Monteiro, S.N. Effect of Chemical Treatment and Length of Raffia Fiber (Raphia vinifera) on Mechanical Stiffening of Polyester Composites. Polymers 2020, 12, https://doi.org/10.3390/polym12122899.

50. Vijay, R.; Vinod, A.; Singaravelu, D.L.; Sanjay, M.R.; Siengchin, S. Characterization of chemical treated and untreated natural fibers from Pennisetum orientale grass-A potential reinforcement for lightweight polymeric applications. Int J Lightweight Mater \& Manuf. 2020, 4, 43-49, https://doi.org/10.1016/j.ijlmm.2020.06.008.

51. Werchefani, M.; Lacoste, C.; Belguith, H.; Gargouri, A.; Bradai, C. Effect of chemical and enzymatic treatments of alfa fibers on polylactic acid bio-composites properties. Journal of Composite Materials 2020 , 54, 4959-4967, https://doi.org/10.1177/0021998320941579.

52. Vijay, R.; Singaravelu, D.L.; Vinod, A.; Sanjay, M.R.; Siengchin, S. Characterization of Alkali-Treated and Untreated Natural Fibers from the Stem of Parthenium Hysterophorus. Journal of Natural Fibers 2021, 18, 80-90, https://doi.org/10.1080/15440478.2019.1612308

53. Plengnok, U; Jarukumjorn, K. Preparation and characterization of nanocellulose from sugarcane bagasse, Biointerface Res Appl Chem. 2020, 10, 5675 - 5678, https://doi.org/10.33263/BRIAC103.675678.

54. Boonsuk, P.; Sukolrat, A.; Bourkaew, S.; Kaewtatip, K.; Chantarak, S.; Kelarakis, A.; Chaibundit, C. Structure-properties relationships in alkaline treated rice husk reinforced thermoplastic cassava starch biocomposites. International Journal of Biological Macromolecules 2021, 167, 130-140, https://doi.org/10.1016/j.ijbiomac.2020.11.157.

55. Ndazi, B.S.; Nyahumwa, C.; Tesha, J. Chemical and thermal stability of rice husks against alkali treatment. Bioresource 2007, 3, 1267-1277.

56. Rahman, M.R.; Islam, M.N.; Huque, M.M.; Hamdan, S.; Ahmed, A.S. Effect of chemical treatment on rice husk (RH) reinforced polyethylene (PE) composites. BioResources 2010, 2, 854-869.

57. Ghani, A.; Hafizuddin, M.; Royan, N.R.; Kang, S.W.; Sulong, A.; Ahmad, S. Effect of alkaline treated rice husk on the mechanical and morphological properties of recycled HDPE/RH Composite. J. Appl. Sci. Agric. 2015, 10, 138-144.

58. Emdadi, Z.; Asim, N.; Yarmo, M.A.; Sopian, K. Effect of Chemical Treatments on Rice Husk ( RH ) Water Absorption Property. Int. J. Chem. Eng. Appl. 2015, 6, 273-276, https://doi.org/10.7763/IJCEA.2015.V6.495.

59. Luna, I.Z.; Dam, K.C.; Chowdhury, A.M.S.; Gafur, M.A.; Khan, R.A. Mechanical and Spectroscopic Properties of Rice Husk Reinforced Polypropylene Composites: Effect of Sodium Hydroxide. Int. J. Compos. Mater. 2015, 6, 162-166, https://doi.org/10.5923/j.cmaterials.20150506.04.

60. Wang, L.; He, C.; Yang, X. Effects of Pretreatment on the Soil Aging Behavior of Rice Husk Fibers/Polyvinyl Chloride Composites. Bioresource 2019, 14, 59-69.

61. Syafri, R.; Ahmad, I.; Abdullah, I. Effect of rice husk surface modification by LENR the on mechanical properties of NR/HDPE reinforced rice husk composite. Sains Malaysiana 2011, 40, 749-756. 
62. Maziad, N.A.; El-Nashar, D.E.; Sadek, E.M. The effects of a silane coupling agent on properties of rice husk-filled maleic acid anhydride compatibilized natural rubber / low-density polyethylene blend. J. Mater. Sci. 2009, 44, 2665-2673, https://doi.org/10.1007/s10853-009-3349-3.

63. Maldas, D. Performance of Hybrid Reinforcements in PVC Composites . II : Use of Surface-Modified Mica and Different Cellulosic Materials as Reinforcements. J. Vinyl Technol. 1993, 15, 38-44, https://doi.org/10.1002/vnl.730150111.

64. Srisuwan, Y.; Baimark, Y.; Suttiruengwong, S. Toughening of Poly ( L-lactide ) with Blends of Poly ( ecaprolactone-co -L-lactide) in the Presence of Chain Extender. Int. J. Biomater. 2018, 2018, https://doi.org/10.1155/2018/1294397. 